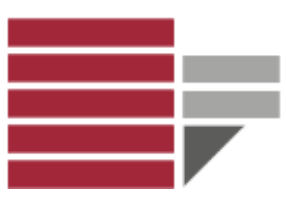
Statistica e Finanza "Giovanni Anania"

Ponte Pietro Bucci, Cubo 0/C

Working Paper n. 06 - 2017

\title{
INNOVATION AND PRODUCTIVITY IN FAMILY FIRMS: EVIDENCE FROM A SAMPLE OF EUROPEAN FIRMS.
}

\author{
Francesco Aiello \\ Dipartimento di Economia, Statistica e Finanza \\ "Giovanni Anania" - DESF \\ Università della Calabria \\ Ponte Pietro Bucci, Cubo 1/C \\ Tel.: +390984 492440 \\ Fax: +390984 492421 \\ e-mail: francesco.aiello@unical.it
}

\author{
Lidia Mannarino \\ Dipartimento di Economia, Statistica e Finanza \\ "Giovanni Anania" - DESF \\ Università della Calabria \\ Ponte Pietro Bucci, Cubo 0/C \\ Tel.: +390984 492405 \\ Fax: +390984 492421 \\ e-mail: lidia.mannarino@unical.it
}

\author{
Valeria Pupo \\ Dipartimento di Economia, Statistica e Finanza "Giovanni Anania" - DESF \\ Università della Calabria \\ Ponte Pietro Bucci, Cubo 0/C \\ Tel.: +390984 492456 \\ Fax: +390984 492421 \\ e-mail: valeria.pupo@unical.it
}

\section{Novembre 2017}

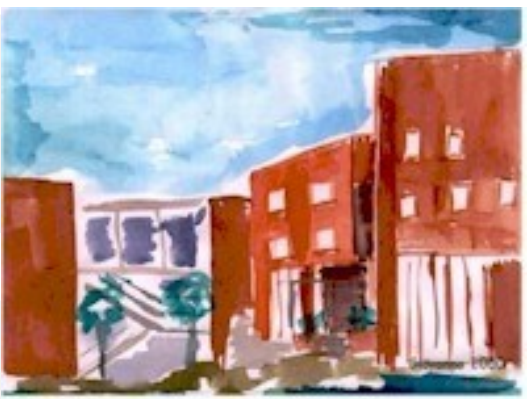

This working paper has been published in Economics of Innovation \& New Technology.

Please cite as follows:

Aiello F., Mannarino L., Pupo V., 2020, "Innovation and productivity in family firms: evidence from a sample of European firms", Economics of Innovation \& New Technology, 29, 4, 394-416 


\title{
Innovation and productivity in family firms: evidence from a sample of European firms.
}

\author{
Francesco Aiello, Lidia Mannarino and Valeria Pupo \\ francesco.aiello@unical.it, lidia.mannarino@unical.it; valeria.pupo@unical.it \\ Department of Economics, Statistics and Finance "Giovanni Anania" \\ University of Calabria \\ I-87036 Arcavacata di Rende (Cosenza) - Italy
}

\begin{abstract}
This paper estimates the impact of $\mathrm{R} \& \mathrm{D}$ investments on the productivity of European family firms. For the period 2007-2009, we consider a Cobb-Douglas production function augmented by R\&D intensity. Specifically, we address the questions of whether the R\&D returns of family firms differ from that of non-family firms. Final outcomes suggest that, on average, non-family firms conducting R\&D record a productivity gain of about 5-8\% compared to non-innovative firms. Additionally, the innovative family firms are about $6 \%$ lower compared to innovative non-family firms. Finally, the rate of return to R\&D of family firms is lower than non-family firms.
\end{abstract}

JEL codes: O30; L60; G34

Keywords: Productivity; R\&D returns; family firms

\section{INTRODUCTION}

The effects of research and development (R\&D) investments on productivity have long been one of the most intriguing fields of research in economics. There is a consensus that advances in knowledge are a key determinant of productivity growth in the long run. In this respect, investments in $R \& D$ directly contribute to knowledge accumulation and therefore any $R \& D$ activity is a source of productivity gains and economic growth.

Innovative efforts are highly heterogeneous over the world. For instance, Europe underperforms compared to major competitors (the USA and Japan) and this is the result of a relatively low level of private R\&D investment (European Commission, 2014). Based on this, the EU dedicates substantial amounts of public money to programs intended to stimulate innovation. As stated both by the Lisbon strategy and the Europe 2020 strategy, all EU members were expected to be investing 3\% of their GDP in R\&D activity within 2020 (2/3 of which should be realized by private funding). This strategy is based on the idea that private incentives to invest in $R \& D$ are insufficient because market failures create a gap between social and private returns to $R \& D$, thereby limiting private incentives to invest in $R \& D$.

From a policy perspective, one would need to measure the marginal returns to $R \& D$ to decide which policies to implement. Two cases are likely. On the one hand, if returns to R\&D are found to be low, then the low private $R \& D$ expenditure is due to $R \& D$ demand shortfalls and the policies should be directed to find opportunities profitable enough for firms, or reduce the cost of inputs through the policies for R\&D investment (size of the market, regulation, the cost and availability of R\&D labour, and so forth). On the other hand, if returns to R\&D are found to be high, there are supply of funds problems (the high cost of capital), highlighting regulation on how financial markets work (Hall and Mairesse, 2009).

Therefore, a justification for programs intended to stimulate innovative activities rests on the literature that estimates the returns to R\&D. Along this line of reasoning, it is not surprising that there is a substantial number of empirical studies assessing the returns to $R \& D$ at country, regional, industry and firm-level (for a review of the literature see Hall, Mairesse 
and Mohnen, 2010; while for meta-analysis studies see Wieser 2005, Moen and Thorsen 2013, and Ugur et al., 2014). Limiting attention to studies at firm level, the evidence reveals a positive relationship between innovation and productivity (among others, see Hall and Mairesse, 1995; Harhoff, 1998; Aiello and Pupo, 2004; Maté-García and RodríguezFernández, 2008; Wakelin, 2001; Rogers, 2010). Unfortunately, this literature has ignored the role of family firms and we have very limited insight about the link between innovation and productivity in family and non-family firms. This is unexpected given that family firms are an extremely common form of business in several countries. For instance, in Europe more than half of all businesses are family controlled and family ownership is the dominant ownership structure even among the biggest firms.

Additionally, from a theoretical point of view there are doubts as to whether family firms are less or more efficient than other firms when investing in R\&D activity. On the one hand, concentrated ownership, effective monitoring, and a thorough understanding of the firm's business model should reduce the agency costs associated with R\&D spending and may have influence on R\&D productivity (Miller and Le Breton-Miller, 2005; Zahra, 2012). On the other hand, risk aversion, resource constraints and fear of losing decision-making control may lead to less efficient R\&D spending in family firms relative to the others (Schulze et al., 2001; Lubatkin et al., 2005).

The fields of research on performance and on innovation of the family business are both huge ones, but relatively little research addresses the overlap between them directly. Indeed, a strand of the literature focuses on the differences in the performance of family and non-family firms (Anderson and Reeb, 2003; Andres, 2008; Barbera and Moores, 2013; Barth et al., 2005; Block et al., 2011; Cucculelli and Micucci, 2008; Cucculelli et al., 2014; Lee, 2006; McConaughy et al., 2001; Miller et al., 2007; Sraer and Thesmar, 2007; Villalonga and Amit, 2006), whereas another explores how innovation differs between family and non-family firms (Block, 2012; Chen \& Hsu, 2009; Gomez-Mejia et al., 2014; Gomez-Mejia et al., 2007, Kotlar et al., 2013; Munoz-Bullon and Sanchez-Bueno, 2011; Sciascia et al., 2015).

To the best of our knowledge, no empirical research focused on this relationship by estimating R\&D returns of family firms. Only the papers by Block (2012) Dieguez-Soto et al., (2016), Classen et al., (2014) provide estimates of the impact of R\&D investments on productivity, but examine the topic from different points of view. Indeed, this research is the first to provide estimates of the magnitude of the impact of $R \& D$ investments on productivity considering the role of ownership. It appears an interesting issue to address because researches that study these topics focused mainly on public firms, while we do not know much about the specific context of private SMEs (Dieguez-Soto et al, 2016, Verhees and Meulenberg, 2004).

In particular, using the firm-level data released by the EFIGE project, we present some empirical evidence on the link between investment in $R \& D$ and productivity for a sample of European manufacturing firms over the period 2007-2009. Adopting the methodology set up by Hall and Mairesse (1995), we estimate R\&D returns of family firms using a Cobb-Douglas production function augmented by the intensity of R\&D expenditure. Final outcomes suggest that on average, relative to non-innovative firms, non-family firms conducting R\&D record productivity increments that are about 5-8 \% higher and that innovative family firms are about $6 \%$ lower compared to innovative non-family firms. Finally family firms have rate of return to R\&D lower than non-family ones.

The remainder of the paper is organised as follows: the next section presents the review of the literature. Section 3 presents the economic model. The description of data, the 
empirical setting and the econometric findings are presented in Section 4. Section 5 discusses the most important results of the research. Section 6 provides some concluding remarks.

\section{REVIEW OF THE LITERATURE}

A firm's capacity to develop and exploit innovation has been shown to be a key determinant of performance and sustained competitive advantage (Bettis \& Hitt, 1995; Helfat \& Peteraf, 2003). Given these circumstances, the link between innovation and productivity becomes critical to develop and/or maintain competitive advantage. Although the fields of research on innovation and productivity of the family business are both huge ones, relatively little research addresses the overlap between them directly (Nieto et al., 2015). From the theoretical point of view, whether family firms exhibit high or low levels of R\&D productivity is an open question.

Family firms are often considered to be different in their agency situation than other firms: ownership and control in the same hands reduce agency costs and align managers' and shareholders' interests (Jensen and Meckling, 1976). This alignment of incentives will encourage managers to take risk decisions aimed at boosting the value of the firm, such as innovation-related decisions. The central argument that portray a positive link between family involvement and innovation is that family firms possess unique resources (Habberson et al. 2003) and characteristics that benefit the implementation of innovation. Exemplary characteristics of family firms that stimulate learning and innovation are their long-term orientation (Zellweger 2007; Miller and Le Breton-Miller, 2005; Ward, 1997), their stewardship behavior (Eddleston and Kellermanns 2006) and their informal sharing of knowledge (Zahra 2012). As family firms have strong incentives to act in the long-term interests of their business, it is more likely that they will support innovation as a source of growth (Zahra, Hayton, and Salvato, 2004).

In other studies, it is believed that the family involvement could generate agency costs (Schulze et al., 2001). Career opportunities, family fortune, and reputation in the community are all linked to the fate of the business in family firms. Since the strategic decisions of family firms have consequences for the family's personal wealth, this leads family businesses to avoid riskier projects that involve greater uncertainty about the performance (Gomez-Mejia et al., 2007; Carney, 2005), such as decisions on innovation strategies (Chen \& Hsu, 2009). Other agency costs may be related to self-control and altruism (Schulze et al., 2001). These problems make it difficult for family firms to recruit, reward, and monitor their managers effectively (Lubatkin et al., 2005), which results in a shortage of qualified managerial talent. Indeed, parental altruism may favour nepotism (Sirmon and Hitt 2003), thus making the hiring of family members more common while also increasing the difficulty of monitoring their performance (Dyer 2006). ${ }^{1}$ In addition, there is a fear among family firms of losing decision-making control and thus they are little inclined to access capital markets or to allow the entry of other investors (Kets de Vries 1993). This limits the possibility of financing innovation activities, by reducing firms ability to exploit existing information. Indeed, assimilating technological knowledge from outside the firm requires a certain degree of

\footnotetext{
${ }^{1}$ Moreover, these problems of self-control hamper the recruitment and promotion of non-family managers (Gedajlovic, Lubatkin, and Schulze 2004), individuals who are so important for the incorporation of new creative knowledge and intangible skills to promote and manage innovation activities (Chen and Hsu 2009; Zahra, 2005). Nepotism and altruism may thus adversely affect the quality of the managers of family businesses and as a result the performance of companies as they are the managers who take strategic decisions on innovation processes (Nieto 2015).
} 
"absorptive capacity", and this is largely determined by firms' R\&D spending (Cohen and Levinthal 1989, 1990). The absorptive capacity also is related to organizational structures. Structures characterized by a high degree of delegation, horizontal communication channels, and incentives that reward knowledge sharing, are conducive to success in absorbing external knowledge and that best support engaging in innovation, but all these organizational practices lead to giving up control (Bennedsen and Foss, 2015). Therefore, family firms may be less disposed to adopt them. In summary, risk aversion, agency costs, resource constraints and organizational structure make family businesses less inclined to invest in innovation.

From the empirical point of view, the literature on returns to $R \& D$ is extensive. A comprehensive overview of earlier work can be found in Mairesse and Sassenou (1991), while Hall, Mairesse and Mohnen (2010) cover more recent studies. Finally, three metaanalysis studies by Wieser (2005), Moen and Thorsen (2013) and Ugur et al. (2014) provide meta-regression evidence on productivity and rates-of-return estimates. ${ }^{2}$ The estimated overall rate of return to $R \& D$ is positive, generally statistically significant and with a magnitude according to the econometric methodology, data level, the measurement of output and of the inputs, the production function used, whether or not it controls for spillovers effects and the method of measuring spillovers (among others, see Hall and Mairesse, 1995; Harhoff, 1998; Aiello and Pupo, 2004; Maté-García and Rodríguez-Fernández, 2008; Wakelin, 2001; Rogers, 2010). ${ }^{3}$ Although family businesses are prevalent in the world, no previous study provides estimates of R\&D returns for family firms. Indeed, the articles that explore family firms focuses on the differences in the performance or in innovation of family and non-family firms.

With respect to the empirical literature that examines whether family businesses have a performance advantage over non-family businesses, the results are mixed as authors report positive, negative and neutral relationships (Anderson and Reeb, 2003; Andres, 2008; Barbera and Moores, 2013; Barth et al., 2005; Block et al., 2011; Cucculelli and Micucci, 2008;

\footnotetext{
${ }^{2}$ Mairesse and Sassenou (1991) and Mairesse and Mohnen (1994) review the literature on innovation and productivity at the firm and industry levels, respectively, and provide a wide range of summary statistics and a comprehensive evaluation of the analytical and empirical dimensions that characterise the research field. A more recent study by Hall, Mairesse and Mohnen (2010) synthesise in a new Elsevier Handbook a very large literature from the past 50 years on the models used in estimating returns to R\&D and on the empirical results that have been achieved using these models. There are also three meta-analysis studies: Wieser (2005) surveys rates-ofreturn estimates at the firm level from 17 primary studies published between 1980-2000, focusing on whether the returns are stable over time and across different countries, industries and econometric specifications; Moen and Thorsen (2013) synthesizes the rate-of-return estimates reported by 41 studies published between 1962-2010 focusing on publication bias, and Ugur et al. (2014) considers 64 econometric studies based on OECD firm or industry data published between 1980 and 2013.

${ }^{3}$ Hall and Mairesse (1995) apply a Cobb-Douglas production function where productivity was regressed on R\&D expenditures, capital and labour of French manufacturing firms (1980-1987). They find a significant impact, ranging from a minimum of 0.22 to a maximum of 0.34 , according to the different specifications and the different econometric estimators adopted. Using the methodology set up by Hall and Mairesse (1995), Harhoff (1998) studies the R\&D/productivity link using a slightly unbalanced panel of 443 German manufacturing over the period 1979-1989, and conclude that the returns to R\&D is 0.22. Similarly, Wakelin (2001) using data on 170 UK quoted firms during the period 1988-1996 shows that the returns to R\&D is around 27\%. This is similar to the estimates of rate of return calculated by Rogers (2010), who in a more recent article find that UK returns to R\&D is around $25 \%$ in the balanced panel ( 86 firms) and $17 \%$ in the unbalanced panel (719 firms) for the period 1989-2000. Aiello and Pupo (2004) also applied a Cobb-Douglas production function to a sample of Italian firms and estimate it at around 20\% over 1989-1994 and 22\% over 1995-1997. Finally, Maté-García and Rodríguez-Fernández (2008) analyse the relationship between productivity growth and R\&D intensity in Spain by using information of 1312 firms between 1993 and 1999 and obtain a rate of return of 0.26.
} 
Cucculelli et al., 2014; Lee, 2006; McConaughy et al., 2001; Miller et al., 2007; Sraer and Thesmar, 2007; Villalonga and Amit, 2006).

With regard to the literature on innovation behavior, the majority of papers finds family firms to be less innovative due to their risk aversion and their longing to preserve socio-emotional wealth (De Massis et al., 2015; Vecchiarini and Calabrò, 2014; Block, 2012; Chen \& Hsu, 2009; Gomez-Mejia et al., 2014; Gomez-Mejia et al., 2007, Kotlar et al., 2013; Munoz-Bullon and Sanchez-Bueno, 2011; Sciascia et al., 2015). In contrast, other studies yield positive results (Ayyagari et al., 2011; Gudmundson et al., 2003; Craig and Dibrell, 2006) and associate the findings to characteristics of family firms, such as their stewardship behaviour, their long-term orientation and informal sharing of knowledge.

To our knowledge only the papers by Block (2012), Classen et al. (2014), Dieguez-Soto et al. (2016) consider both strands of this literature, by providing estimates of the impact of R\&D investments on performance, but they examine the topic from a different point of view and do not estimate R\&D returns. In particular, Block (2012) considers large publicly listed U.S. firms and address whether family firms exhibit high or low levels of R\&D spending and R\&D productivity by comparing the behavior of family businesses, as a group, with companies that have a sole founder and non-family businesses. He finds that while family ownership decreases the level of R\&D intensity, ownership by lone founders has a positive effect not only on R\&D intensity but also on the level of R\&D productivity. Using data from the Community Innovation Survey on 2,087 German small- and medium-sized enterprises (SMEs), Classen et al. (2014) provide an exploratory analysis of differences between family and non-family firms in innovative investments, product and process innovation outcomes, and labor productivity. They show that family SMEs invest in innovation less intensively than their non-family counterparts and achieve an at least equal level of product innovation output and a presumably superior level of cost savings from process innovation. However, family SMEs exhibit a lower labor productivity in comparison to non-family SMEs. Finally, using a panel data sample of 551 Spanish manufacturing small- and medium-sized enterprises (SMEs), Dieguez-Soto et al. (2016) study the moderating role of family management in the relationships between the intensity of $\mathrm{R} \& \mathrm{D}$ and the occurrence of continuous technological innovation, and between the existence of technological innovation outcomes and long-term firm performance measured by the return on assets. They find that family management reduces efficiency in the conversion of $R \& D$ expenses into technological innovation outcomes over time. They also consider that the influence of family management significantly contributes to improve the effect of the achievement of technological innovation on long-term performance.

\section{THE ECONOMIC MODEL}

In order to investigate the impact of $\mathrm{R} \& \mathrm{D}$ investments on firm productivity, we used the approach proposed by Griliches (1986). We consider a Cobb-Douglas production function augmented by $\mathrm{R} \& \mathrm{D}$ intensity. Let

$$
Y_{i t}=A_{i} e^{\lambda t} K_{i t}^{\alpha} L_{i t}^{\beta} T_{i t}^{\gamma} e^{\varepsilon_{i t}}
$$

be a production function where $Y_{i t}$ is the output of the $i$-th firm at time $t ; L_{i t}, K_{i t}$, and $T_{i t}$ are the inputs used in the productive process $\left(L_{i t}\right.$, states for labor, $K_{i t}$, is the physical capital, and $T_{i t}$ represents the stock of technological capital). $\alpha, \beta$, and $\gamma$ are the output elasticity and $A_{i}$ is a parameter of scale; $\varepsilon_{i t}$ is the disturbance that captures the unobservable firm specific effects 
and any unforeseen event (such as unexpected change of inputs or of institutional context). The coefficient $\lambda$ is a measure of disembodied technological change.

The firm's output behaviour over time can be illustrated by taking logs and derivative of eq. [1], which, in log-linear form, is:

$$
\dot{Y}_{i t}=\lambda+\beta \dot{L}_{i t}+\alpha \dot{K}_{i t}+\gamma \dot{T}_{i t}+\mu_{i t}
$$

In eq. [2] each variable $\dot{Y}_{i t}, \dot{L}_{i t}, \dot{K}_{i t}$ and $\dot{T}_{i t}$ is a growth rate and the coefficients to be estimated are elasticities. In the absence of long time series needed to measure $T$, the production approach still remains valid for understanding the role of innovation, as it allows estimation of the returns to R\&D, say $\phi$, instead of the elasticity $\gamma$. Provided that $\gamma=\frac{\delta \mathrm{Y} / \mathrm{Y}}{\delta \mathrm{T} / \mathrm{T}}$ and taking into consideration the relationship between $\phi$ and $\gamma$, that is $\phi=\frac{Y_{i t}}{T_{i t}} \gamma$ (Terleckyj, 1974), the eq. [2] becomes:

$$
\dot{Y}_{i t}=\lambda+\beta \dot{L}_{i t}+\alpha \dot{K}_{i t}+\phi\left(\frac{R \& D_{i t}}{Y_{i t}}\right)+\mu_{i t}
$$

In eq. [3] it is assumed that $R \& D$ investments are a good proxy of the annual change of technological capital. Estimations of $\phi$ assess the impact of R\&D intensity on the production growth and are to be meant as returns to $R \& D$ before depreciation.

A variant of eq. [3] is obtained by expressing the production function as output per worker. By dividing the eq. [1] by L one gets:

$$
\frac{Y_{i t}}{L_{i t}}=A_{i} e^{\lambda t}\left(\frac{K_{i t}}{L_{i t}}\right)^{\alpha} L_{i t}^{\eta} T_{i t}^{\gamma} e^{\varepsilon_{i t}}
$$

where $\eta=\alpha+\beta-1$, is the departure from the assumption of constant returns to scale for traditional inputs (labour and physical capital). When maintaining the same assumptions on the $R \& D$ capital and expressing each variable as growth rates, one obtains:

$$
\dot{y}_{i t}=\lambda+\eta \dot{L}_{i t}+\alpha \dot{k}_{i t}+\phi\left(\frac{R \& D_{i t}}{Y_{i t}}\right)+\mu_{i t}
$$

Differently from eq. [3], here, $\dot{y}$ and $\dot{k}$ are the growth rates of labour productivity and of physical capital per worker. The parameter $\eta$ allows testing of the hypothesis of constant returns to scale with respect to conventional inputs, that is, labour and physical capital.

\section{EMPIRICAL ANALYSIS}

The empirical analysis is based on the EU-EFIGE data which is a database collected from the EFIGE "European Firms in a Global Economy: internal policies for external competitiveness" project. This is supported by the Directorate General Research of the European Commission through its 7th Framework Programme and coordinated by Bruegel (for details, see Altomonte et al., 2012). The dataset contains data from a survey and from balance-sheets. Data was collected in 2010 and covers the years from 2007 to 2009. The EFIGE survey covers a representative sample of manufacturing firms with more than ten employees in seven 
European countries (Austria, France, Germany, Hungary, Italy, Spain and the UK) and combines measures of firms' international activities with quantitative and qualitative information ranging from $R \& D$ and innovation, labour organisation, financing and organisational activities, and pricing behaviour. Since firms that originally reported a number of employees equal to or larger than 500 in the EFIGE dataset are capped at 500 employees, we have restricted our sample to firms with a number of employees between 10 and $499 .{ }^{4}$

In what follows we refer to the sample formed by 3,553 European firms. The empirical model used in the analysis is driven by data availability. The EFIGE dataset provides only one observation of the key variable of the analysis, that is, the R\&D intensity defined as the percentage of the total turnover invested in R\&D. It is averaged over the threeyears period 2007-2009 covered by the survey. As the EFIGE dataset is matched with AMADEUS, the variables $\mathrm{y}, \mathrm{k}$ and 1 of eq. [5] are calculated as the growth rate between the years 2010-2011. In particular, the dependent variable is the rate of growth of labour productivity, expressed as sales to workers, while the physical capital is given by the value of fixed-assets per worker.

In order to take account of the role of family firms, the model is augmented to include the interaction between R\&D and family, where the dummy family is unity if the firm is directly or indirectly controlled by an individual or family-owned entity in the 2007-2009 period and zero otherwise.

It should also be noted that eq. [5] has been augmented by a set of sector dummies, which are meant to control for specific characteristics of the industry to which firms belong. The dummy variables reflect the Pavitt classification (Pavitt, 1984). In this way the bias due to sector-specific unobservable heterogeneity is reduced. Additionally, given that firm performance is influenced by the territorial specificities of the regions where they operate, we included the R\&D intensity of the private sector (R\&D_region), measured as the share of private R\&D expenditure in regional GDP in 2007 (data are from EUROSTAT).

In order to study how firms' productivity growth is related to $R \& D$, we adopt the estimation strategy proposed by Crepon et al. (1998), which estimated a model that establishes a link between innovation input, innovation output and firm performance measured in terms of productivity. Similar to the original CDM model, we rely on a two-step structural model. More specifically, we follow the econometric approach used by Medda and Piga (2014). Building on eq. (5), we estimate two related types of models of productivity growth:

$$
\begin{aligned}
& \dot{y}_{i}=\eta \dot{L}_{i}+\alpha \dot{k}_{i}+\phi_{1} R \& D_{-} \text {dummy }_{i}+\tau_{1} \text { FamilyR \&D_dummy }_{i}+\beta_{1} X_{i}+u_{i} \\
& \dot{y}_{i t}=\eta \dot{L}_{i}+\alpha \dot{k}_{i}+\phi_{2}\left(\frac{R \& D_{i}}{Y_{i}}\right)+\tau_{2} \text { Family }\left(\frac{R \& D_{i}}{Y_{i}}\right)+\beta_{2} X_{i}+e_{i}
\end{aligned}
$$

where $\mathrm{R} \& \mathrm{D} \_$dummy $y_{\mathrm{i}}$ is a dummy indicating whether firm $i$ is engaged in $\mathrm{R} \& \mathrm{D},(\mathrm{R} \& \mathrm{D} / \mathrm{Y})_{i}$ is the ratio of firm $i$ 's own $R \& D$ spending $\left(R \& D_{i}\right)$ over total sales $\left(Y_{i}\right)$, FamilyR\&D is the interaction between $R \& D$ (dummy or intensity) and family, $X_{i}$ is a vector of exogenous

\footnotetext{
${ }^{4}$ The number of observations which we lost, that is, the number of firms with a number of employees greater or equal to 500 , was 397 out of the 14,880 .
} 
variables such as Pavitt dummies and $R \& D$ region, plus a constant; $u_{i}$ and $e_{i}$ are classical disturbance terms.

A potential selection problem in estimating eq. [6] may arise because the sample of firms involved in $R \& D$ is not random, i.e., firms rationally determine whether to invest in $R \& D$ and the level of $R \& D$ investments may be related to the expected gain in productivity. Therefore, $R \& D$ represents an endogenous treatment.

We try to correct the bias due to an endogenous variable by following two strategies.

First, the econometric strategy builds upon the literature on treatment effects (Wooldridge , 2002). In the treatment effect model, a dummy variable indicating the treatment condition $\mathrm{R} \& \mathrm{D}_{-}$dummy $y_{\mathrm{i}}$ (i.e., $\mathrm{R} \& \mathrm{D}_{\mathrm{i}}=1$ if firm $i$ is in the treatment condition, and $\mathrm{R} \& \mathrm{D}_{\mathrm{i}}=0$ otherwise) is directly entered into the equation and the outcome variable $\mathrm{y}_{i}$ of the regression equation is observed for both $R \& D_{i}=1$ and $R \& D_{i}=0$. Specifically, the treatment effect model is expressed in two equations: the eq. [6] and the selection equation that can be modeled according to the following probit specification:

$R \& D \_d u m m y_{i}^{*}=\gamma z_{i}+u_{i}$

where R\&D_dummy $=1$ if $R \& D$ spending $>0$ and $R \& D \_$dummy $=0$ if $R \& D$ spending $=0$, and $\mathrm{Z}_{\mathrm{i}}=\mathrm{X}_{\mathrm{i}}+\mathrm{W}_{\mathrm{i}}, \mathrm{W}_{\mathrm{i}}$ is a vector of variables which explain, along with $\mathrm{Xi}$, a firm's decision to engage in R\&D. The residuals in [6] and [6a] are correlated as follows:

$\left(\begin{array}{l}u_{i} \\ \varepsilon_{i}\end{array}\right) \approx N\left[\left(\begin{array}{l}0 \\ 0\end{array}\right),\left(\begin{array}{cc}\sigma_{u} & \sigma_{u e} \\ \sigma_{u e} & 1\end{array}\right)\right]$

If $\sigma_{u \varepsilon} \neq 0$, then R\&D_dummy is endogenous in [6a], and OLS would produce biased estimates. The treatment effect model illustrated above can be estimated in a two-step procedure similar to the standard two-step procedure illustrated in Heckman (1979).

Second, following the procedure outlined in Wooldridge (2002, pp. 621-625), the fitted values from [6a] are employed as an instrument for $R \& D \_d u m m y_{i}$, and [6] is then estimated using instrumental variables (IV) techniques.

In eq. [7], the selection mechanism involves both the decision of whether to invest in R\&D as well as how much to invest. To account for both forms of endogeneity we follow Wooldridge (2002, pp. 643-644) and first, we calculate the predicted values from the following Tobit model:

$\left(\frac{R \& D_{i}}{Y_{i}}\right)=\gamma W_{i}+v_{i}$

These are used as instruments for $(R \& D / Y)_{\mathrm{i}}$ in the IV estimation of [7]. To estimate [6a] and [9], the set of exogenous variables were chosen according to the previous similar works on this field of research. We include pavitt dummies, firm size, affiliation to a group, firm age, human capital, the ratio of long and short term debt, a dummy equal to one if the firm is an exporting firm as control variables in all equations.

The obtained empirical results from probit and tobit estimates of the selection equations [6a] and [9] are presented in Appendix A, where the dependent variables are, respectively, whether a firm is engaged in $R \& D$ activities (column 1), and the R\&D intensity (column 2). The models in Appendix A are used to obtain the inverse Mill's ratio $(\lambda)$ and the 
fitted values needed as instruments in the productivity Eq. [6] and [7], whose estimates, obtained using the procedures discussed above, are reported in Table 1.

Table 1. R\&D and productivity - Dependent variable: Productivity growth

(3)

Treatment Wooldridge 2SLS, probit Wooldridge 2SLS; effect model selection tobit selection

\begin{tabular}{lcc}
\hline Capital Intensity & $0.0163 * *$ & $0.0159 * *$ \\
& $(2.18)$ & $(2.09)$ \\
Labour & $-0.259 * * *$ & $-0.2632 * * *$ \\
& $(-14.45)$ & $(-14.40)$ \\
Pavitt2 & -0.0046 & -0.0074 \\
& $(-0.71)$ & $(-1.06)$ \\
Pavitt3 & -0.0018 & -0.002 \\
& $(-0.24)$ & $(-0.27)$ \\
Pavitt4 & -0.0207 & -0.0213 \\
& $(-1.45)$ & $(-1.45)$ \\
R\&D_region & $4.42 \mathrm{E}-09$ & $3.53 \mathrm{E}-09$ \\
& $(1.33)$ & $(0.89)$ \\
R\&D_dummy & $0.0559 * * *$ & $0.0852 * * *$ \\
& $(3.25)$ & $(2.62)$ \\
FamilyR\&D_dummy & -0.0113 & $-0.0615 * * *$ \\
& $(-1.39)$ & $(-2.38)$
\end{tabular}

R\&D Intensity $2.018 * *$

FamilyR\&D Intensity $-1.948 * *$

_cons $\quad 0.0227 * * *$

$0.0273 * * *$ $0.0275 * * *$

\begin{tabular}{lc} 
& $(2.80)$ \\
\hline Lambda $(\lambda)$ & -0.0234 \\
rho & -0.1532 \\
sigma & 0.1527 \\
LR test of $($ rho $=0)$ & 4.95 \\
${\text { Prob }>\text { chi }^{2}}^{2}$ & 0.0260
\end{tabular}

$N$

(3.96) (3.24)

$t$ statistics in parentheses

${ }^{*} p<0.10,{ }^{* *} p<0.05,{ }^{* * *} p<0.01$ 
Columns 1 and 2 show the result when the dummy for R\&D is a regressor and we employ either the treatment effect model (column 1) or Wooldridge's Instrumental Variable approach (column 2). The column (3) includes the level of R\&D spending, instrumented by the predicted values from [9]. Before presenting the results, it is noteworthy to point out that the column 1 presents the treatment effect model along with lambda parameter that verifies the presence of endogeneity in the original model. The statistic lambda is the inverse Mills ratio which is the product of two terms: $\lambda=\sigma_{u} \rho$, where $\rho$ is the correlation between error term of equation [6], and the error term of the probit model [6a]. If $\rho=0$ then $\lambda=0$ and the problem reduces to one estimable by OLS; if $\rho$ is positive (negative), $\lambda$ is positive or negative and the OLS overestimates (underestimates) the treatment effect. The LR test of $\rho$ (rho) is a comparison of the joint likelihood of an independent probit model for the selection equation and a regression model on the observed data against the treatment effect model likelihood. Given that chi $^{2}=4.95(\mathrm{p}<0.02)$ (Table 1$)$, we can reject the null hypothesis at a statistically significant level and conclude that $\rho$ is not equal to 0 . This suggests that applying the treatment effect model is appropriate.

The results of table 1 show that the influence of Capital intensity, over productivity growth is positive and it is statistically significant in all specifications. The variable labour has a coefficient that is significantly different from zero and with negative sign, thereby indicating that the production function exhibits decreasing returns to scale.

The estimates displayed in the first two columns of Table 1 are very similar: both treatment effect model and Wooldridge's procedure provide positive and significant estimates of the effect of conducting R\&D, with coefficients, respectively, of 0.05 and 0.08 (i.e., relative to non-innovative firms, on average the non-family firms conducting R\&D records productivity increments that are about 5-8\% higher).

The results for the private return to $R \& D$ expenditures (column 3), are qualitatively similar to the ones where the innovative activity is proxied by a dummy (the coefficient is statistically significant and has a positive sign). This means that technological efforts boost productivity. In accordance with the estimations, we observe that the rate of return to $R \& D$ investment $(\phi)$ is about 2,02. Thus, a $10 \%$ increase in R\&D intensity increases labour productivity by about $20 \%$.

It should be pointed out that relative to innovative non-family firms, family firms record productivity increments that are about 1-6\% lower when considering column (1) and (2).

Regarding, on the other hand, the rate of return on R\&D (column 3) is lower than $1.9 \%$ compared with non-family businesses, implying that family businesses fail to meet the standards of productivity of non-family businesses.

\section{DISCUSSION}

The analysis aimed to verify whether family firms perform differently from non-family firms. As the main result when focusing on $R \& D$ activity, family firms have rate of return to $R \& D$ lower than non-family firms, it can be argued that the massive presence of family businesses reduces the average rate of return of $R \& D$ in Europe. Some explanations of this outcome are provided in the following.

A first interpretation is that the $R \& D$ return is determined by the quality of family firm managers. High agency costs because of problems related to self-control and parental altruism (Schulze et al. 2001) make it difficult for family firms to recruit, reward and monitor their managers effectively (Lubatkin et al., 2005). The final result is a shortage of qualified 
managerial talent, that is, the managers who are charged with deciding on innovation processes.

Another factor affecting our evidence regards the resource constraints that limit the possibility of initiating innovation projects. Because of the fear of losing decision-making control, family firms are little inclined to access capital markets or to allow the entry of other investors (Kets de Vries 1993). This limits the possibility of financing innovation activities, by reducing the firm's ability to exploit existing information. Indeed, assimilating technological knowledge from outside the firm requires "absorptive capacity", and this is largely determined by firms' R\&D spending (Cohen and Levinthal 1989, 1990). The absorptive capacity also is related to organizational structures. Structures characterized by a high degree of delegation, horizontal communication channels, and incentives that reward knowledge sharing, are conducive to success in absorbing external knowledge and that best support engaging in innovation, but all these organizational practices lead to giving up control (Bennedsen and Foss, 2015). Therefore, family firms may be less disposed to adopt them.

Finally, family firms have the stable network relations to the family firm multiple stakeholders, which are a source of access to external knowledge of use in the innovation. However, such networks may be less conducive to innovation over time, because knowledge redundancy increases as networks become tighter and closer. In a slowly moving environment this may not pose a major problem while if change is frequent, firms need to renew themselves, and ties that are too strong can then create problems (Bennedsen and Foss, 2015).

\section{CONCLUSIONS}

The role of $R \& D$ in the generation of productivity growth is one of the most important issues in economics. Although family businesses are prevalent in several countries, there are few papers directly addressing the relationship between family performance and innovation. No study focuses on the relationship between the returns to R\&D and family control.

Using a large data set of about 3500 European firms this paper has analysed the link between $R \& D$ and productivity, using specifications that estimate the rate of return of $R \& D$ investments.

This paper allows three main conclusions to be drawn. The first result is that the returns of $R \& D$ of innovative non-family firms are positive and are around 5-8 \% higher compared to non-innovative firms. While this is not a novelty in this area of research, we find some differences between firm-groups. This introduces the second main result of the study, which concerns the fact that innovative family firms record productivity increments that are about $6 \%$ lower than innovative non-family firms. Finally, the rate of return on R\&D of family firms is lower than $1,9 \%$ compared with non-family businesses, implying that family businesses fail to meet the standards of productivity of non-family businesses.

The lower R\&D return can depend on the quality of family firms' managers, lower absorptive capacity due resource constraints that limit the possibility of initiating innovation projects and organizational structures that support engaging in innovation to a lesser extent. This result may be also driven by tighter and closer networks which are part of the family environment and are less conducive to innovation. 


\section{REFERENCES}

Aiello, F., Pupo, V., 2004. Il tasso di rendimento degli investimenti in ricerca e sviluppo delle imprese innovatrici italiane. Rivista di Politica Economica, 81-117.

Altomonte, C., Aquilante, T., and Ottaviano, G.I.P., 2012. The Triggers of Competitiveness: The EFIGE Cross-Country Report. Bruegel Blueprints Series 17(738): 1-67.

Anderson, R., Reeb, D. 2003. Founding-family ownership and firm performance: Evidence from S\&P 500. Journal of Finance, 58, 653-684.

Andres, C., 2008. Large shareholders and firm performance. An empirical examination of founding-family ownership. Journal of Corporate Finance, 14 (4), 431-445.

Ayyagari, M., Demirguc,-Kunt, A., and Vojislav, M., 2011. Firm innovation in emerging markets: The role of finance, governance, and competition. Journal of Financial and Quantitative Analysis, 46(6), 1545-1580.

Barbera, F., Moores, K., 2013. Firm ownership and productivity: A study of family and nonfamily SMEs. Small Business Economics, 40(4), 953-976.

Barth, E., Gulbrandsen, T., and Schone, P., 2005. Family ownership and productivity: The role of owner-management. Journal of Corporate Finance, 11(1-2), 107-127.

Bettis, R.A., Hitt, M.A., 1995. The new competitive landscape. Strategic Management Journal, Summer Special Issue, 16, 7-19.

Block, J. H., 2012. R\&D investments in family and founder firms: An agency perspective. Journal of Business Venturing, 27(2), 248-265. doi:10.1016/j.jbusvent.2010.09.003.

Block, J., Jaskiewicz, R. and Miller, D., 2011. Ownership Versus Management Effects on Performance in Family and Founder Companies: A Bayesian Reconciliation. Journal of Family Business Strategy 2(4), 232- 245.

Bennedsen M., Foss, N., 2015, Family Assets and Liabilities in the Innovation Process. California Management Review, 58(1), 65-81.

Carney, M., 2005. Corporate Governance and Competitive Advantage in Family-Controlled Firms. Entrepreneurship Theory and Practice, 29(3), 249-265.

Chen, H. L., Hsu, W. T., 2009. Family, Ownership, Board Independence, and R\&D Investment. Family Business Review, 22(4), 347-362.

Classen, N., Carree, M., Van Gils, A., and Peters, B., 2014. Innovation in family and nonfamily SMEs: an exploratory analysis. Small Business Economics, 42, 595-609.

Cohen, W., Levinthal, D., 1989. Innovation and Learning: The Two Faces of R\&D. The Economic Journal, 99(397), 569-596.

Cohen, W., Levinthal, D., 1990. Absorptive Capacity: A New Perspective on Learning and Innovation. Administrative Science Quarterly, 35, 128-152.

Cong, R., \& Drukker, D. M. (2000). Treatment effects model. Stata Technical Bulletin, May.

Craig, J. B. L., Dibrell, C., 2006. The natural environment, innovation, and firm performance: A comparative study. Family Business Review, 19(4), 275-288.

Crepon, B., Duguet, E., Mairesse, J., 1998. Research, innovation and productivity: an econometric analysis at the firm level. Econ. Innov. New Technol., 7:115-158.

Cucculelli, M., Micucci, G., 2008. Family succession and firm performance. Journal of Corporate Finance, 14 (1), 17-31.

Cucculelli, M., Mannarino, L., Pupo, V., and Ricotta F., 2014. Owner-Management, Firm Age, and Productivity in Italian Family Firms. Journal of Small Business Management, 52(2), 325-343. 
De Massis, A., Frattini, F., Pizzurno, E., \& Cassia, L. (2015). Product Innovation in Family versus Nonfamily Firms: An Exploratory Analysis. Journal of Small Business Management, 53(1), 1-36.

Diéguez-Soto, J., Manzaneque, M.,, and Rojo-Ramírez, A. A., 2016. Technological Innovation Inputs, Outputs, and Performance: The Moderating Role of Family Involvement in Management. Family Business Review, $1-20$.

Dyer Jr, W. G., 2006. Examining the "Family Effect" on Firm Performance. Family Business Review, 19(4), 253-273.

Eddleston, K. A., Kellermanns, F. W., 2006. Destructive and productive family relationships: A stewardship theory perspective. Journal of Business Venturing, 22(4), 545-565.

European Commission, 2014, Research and innovation performance in the EU. Innovation Union progress at country level. Edited by Directorate-General for Research and Innovation. Printed in Luxembourg.

Gedajlovic, E., Lubatkin, M. and Schulze W., 2004. Crossing the Threshold from Founder Management to Professional Management. Journal of Management Studies, 41(5), 899-912.

Gomez-Mejia, L., Campbell, J., Martin, G., Hoskisson, R., Makri, M. and Sirmon, D., 2014. Socioemotional wealth as a mixed gamble: revisiting family firm R\&D investments with the behavioral agency model. Entrepreneurship Theory and Practice, 38(6), 13511374.

Gomez-Mejia, L. R., Haynes, K. T., Núñez-Nickel, M., Jacobson, K. J., and Moyano-Fuentes, J., 2007. Socioemotional wealth and business risks in family-controlled firms: Evidence from Spanish olive oil mills. Administrative science quarterly, 52(1), 106137.

Griliches, Z., 1986. Productivity, R\&D, and basic research at the firm level in the 1970s. American Economic Review, 76, 14 I- 154.

Gudmundson, D., Tower, C. B., and Hartman, E. A., 2003. Innovation in small businesses: Culture and ownership structure do matter. Journal of Developmental Entrepreneurship, 8(1), 1-18.

Habbershon, T.G., Williams, M.L., and MacMillan, I.C., 2003. A unified systems perspective of family firm performance. Journal of Business Venturing, 18 (4), 451-465.

Hall, B. H., Mairesse, J., 2009. Corporate R\&D Returns. In European Commission, Knowledge for Growth, Prospects for science, technology and innovation, 17-22, Bruxelles

Hall, B. H., Mairesse, J., and Mohnen, P., 2010. Measuring the Returns to R\&D. In Hall, B. H. and N. Rosenberg, Handbook of the Economics of Innovation, 1034-1076. Amsterdam and New York: Elsevier.

Hall, B.H., Mairesse, J., 1995. Exploring the relationship between R\&S and productivity in French manufacturing firms. Journal of Econometrics, 65, 265-293.

Harhoff, D., 1998. R\&S and productivity in German manufacturing firms. Economics of Innovations and New Technology, 6, 29-49.

Heckman, J., 1979. Sample selection bias as a specification error. Econometrica, 47,153-161.

Helfat, C.E., Peteraf, M.A., 2003. The dynamic resource-based view: capability lifecycles. Strategic Management Journal, 24, 997-1010.

Jensen, M. C., Meckling, W.H., 1976. Theory of the Firm: Managerial Behavior, Agency Costs and Ownership Structure. Journal of Financial Economics, 3, 305-360. 
Kets de Vries, M. F. R., 1993. The Dynamics of Family Controlled Firms: The Good and the Bad News. Organizational Dynamics, 21(3), 59-71.

Kotlar, J., De Massis, A., Frattini, F., Bianchi, M., and Fang, H., 2013. Technology Acquisition in Family and Nonfamily Firms: A Longitudinal Analysis of Spanish Manufacturing Firms. Journal of Product Innovation Management, 30(6), 1073-1088.

Lee, J., 2006. Family firm performance: Further evidence. Family Business Review, 19 (2), 103-114

Lubatkin, M. H., Schulze, W.S., Ling, Y., and Dino, R.N., 2005. The Effects of Parental Altruism on the Governance of Family- Managed Firms. Journal of Organization Behavior, 26, 313-330.

Mairesse, J., Sassenou, M., 1991. R\&D and productivity: a survey of econometric studies at the firm level. STI Review, OECD, 8, 9-46.

Mairesse, J., Mohnen P., 1994. R\&D and productivity growth: What have we learned from econometric studies?, Eunetic Conference on Evolutionary Economics of Technological Change: Assessment of Results and New Frontiers, 817-888, Strasbourg.

Maté-García, J. J., Rodríguez-Fernández, J. M. , 2008. Productivity and R\&D: an econometric evidence from Spanish firm-level data». Applied Economics, 40, 1827-1837.

Medda, G., Piga, C.A., 2014. Technological spillovers and productivity in Italian manufacturing firms. Journal of Productivity Analysis, 41, 419-434.

McConaughy, D., Matthews, C., and Fialko, A. S., 2001. Founding Family Controlled Firms: Efficiency, Risk, and Value. Journal of Small Business Management 39(1), 3150.

Miller, D., Le Breton-Miller, I., Lester, R., Cannella Jr., A.A., 2007. Are family firms really superior performers? Journal of Corporate Finance, 13 (4) (2007), 829-858.

Miller, D., Le Breton-Miller, I., 2005. Managing for the Long Run: Lessons in Competitive Advantage from Great Family Businesses. Harvard Business School Press, Boston.

Møen, J., Thorsen, H. S., 2013. Publication bias in the returns to R\&D literature. Institut for Foretaksøkonomi, Discussion Paper, No. 2013/12.

Munoz-Bullon, F., Sanchez-Bueno, M. J., 2011,. The Impact of Family Involvement on the R\&D Intensity of Publicly Traded Firms. Family Business Review, 24(1), 62-70.

Nieto, M.J., Santamaria, L., Fernandez S., 2015. Understanding the Innovation Behavior of Family Firms. Journal of Small Business Management, 53(2), 382-399.

Pavitt, K., 1984. Sectoral Patterns of Technical Change: Towards a Taxonomy and a Theory. Research Policy, 13, 343-73.

Rogers, M., 2010. R\&D and productivity: using UK firm-level data to inform policy. Empirica, 37, 329-359

Schulze, W. S., Lubatkin, M. H., Dino, R. N., and Buchholtz, A. K., 2001. Agency Relationships in Family Firms: Theory and Evidence. Organization Science 12(2), 99116.

Sciascia, S., Nordqvist, M., Mazzola, P., and De Massis, A., 2015. Family Ownership and R\&D Intensity in Small- and Medium-Sized Firms. Journal of Product Innovation Management, 32(3), 349-360.

Sirmon, D. G., Hitt, M.A., 2003. Managing Resources: Linking Unique Resources, Management, and Wealth Creation in Family Firms. Entrepreneurship Theory and Practice, 27(4), 339-358. 
Sraer, D., Thesmar, D., 2007. Performance and behavior of family firms: Evidence from French stock market. Journal of European Economic Association, 5 (4), 709-751.

Terleckyj, N., 1974. Effects of R\&S on the Productivity Growth of Industries: An Exploratory Study, Nation Planning Association, New York.

Ugur, M., Guidi, F., Solomon, E., Trushin, E., 2014. R\&D investment, productivity and rates of return: A meta-analysis of the evidence on OECD firms and industries, http://mpra.ub.uni-muenchen.de/59686/ - MPRA Paper No. 59686, posted 7. November 2014 12:23 UTC.

Vecchiarini, M., Calabrò, A., 2014. What we don't know yet about innovation in family firms: a systematic literature review and guidance for future research. European Academy of Management Conference Proceedings, Valencia, June 4-7.

Verhees, F. J. H. M., Meulenberg, M. T. G., 2004. Market orientation, innovativeness, product innovation, and performance in small firms. Journal of Small Business Management, 42, 134-154.

Villalonga, B., Amit, R., 2006. How Do Family Ownership, Management and Control Affect Firm Value?. Journal of Financial Economics, 80, 385-417.

Wakelin, K., 2001. Productivity growth and R\&S expenditure in UK manufacturing firms. Research Policy, 20, 1079-1090.

Ward, J. L., 1997. Growing the Family Business: Special Challenges and Best Practices. Family Business Review, 10(4), 323-337.

Wieser, R., 2005. Research and Development Productivity and Spillovers: Empirical Evidence at the Firm Level. Journal of Economic Surveys, 19(4), 587-621.

Wooldridge, J. 2002. Econometric analysis of cross section and panel data. The MIT Press, Cambridge.

Zahra, S. A., 2012. Organizational learning and entrepreneurship in family firms: Exploring the moderating effect of ownership and cohesion. Small Business Economics, 38(1), $51-65$.

Zahra, S. A., 2005. Entrepreneurial Risk Taking in Family Firms. Family Business Review, 18(1), 23-40.

Zahra, S. A., Hayton, J.C., and Salvato, C., 2004. Entrepreneurship in Family vs. Non-family Firms: A Resource Based Analysis of the Effect of Organizational Culture. Entrepreneurship Theory and Practice, 28(4), 363- 381.

Zellweger, T. M., 2007. Time horizon, costs of equity capital, and generic investment strategies of firms. Family Business Review, 20(1), 1-15. 
Appendix A

Table A1. R\&D activity; Determinants of choice

\begin{tabular}{|c|c|c|}
\hline & (1) & (2) \\
\hline & PROBIT & TOBIT \\
\hline \multirow[t]{2}{*}{ Pavitt1 } & $-0.646^{* * * *}$ & $-0.0546^{* * * *}$ \\
\hline & $(-5.27)$ & $(-5.48)$ \\
\hline \multirow[t]{2}{*}{ Pavitt2 } & $-0.504^{* * *}$ & $-0.042^{* * *}$ \\
\hline & $(-3.97)$ & $(-4.06)$ \\
\hline \multirow[t]{2}{*}{ Pavitt3 } & $-0.373^{* * *}$ & $-0.035^{* * *}$ \\
\hline & $(-2.87)$ & $(-3.36)$ \\
\hline \multirow[t]{2}{*}{ Exporting firm } & $0.642^{* * *}$ & $0.054^{* * *}$ \\
\hline & $(12.83)$ & $(10.92)$ \\
\hline \multirow[t]{2}{*}{ Human Capital } & 0.035 & 0.0003 \\
\hline & $(1.30)$ & $(1.49)$ \\
\hline \multirow[t]{2}{*}{ Group } & 0.088 & -0.0005 \\
\hline & (1.44) & $(-0.10)$ \\
\hline \multirow[t]{2}{*}{ d_young } & -0.034 & 0.0111 \\
\hline & $(-0.32)$ & $(1.12)$ \\
\hline \multirow[t]{2}{*}{ d_med_age } & -0.013 & $0.0066^{*}$ \\
\hline & $(-0.29)$ & $(1.51)$ \\
\hline \multirow[t]{2}{*}{ Short term debts } & $0.001^{* *}$ & 0.000 \\
\hline & $(2.16)$ & $(0.84)$ \\
\hline \multirow[t]{2}{*}{ Long term debts } & $0.001^{* * *}$ & $0.0001^{* *}$ \\
\hline & $(2.82)$ & $(2.52)$ \\
\hline \multirow[t]{2}{*}{ Firm size } & $0.216^{* * *}$ & $0.0051^{* *}$ \\
\hline & $(7.12)$ & $(1.86)$ \\
\hline \multirow[t]{2}{*}{ R\&D_region } & 0.000 & 0.000 \\
\hline & $(0.96)$ & $(0.84)$ \\
\hline \multirow[t]{2}{*}{ cons } & $-0.732^{* * *}$ & $-0.0315^{* * *}$ \\
\hline & $(-4.52)$ & $(-2.25)$ \\
\hline \multirow[t]{2}{*}{ Sigma_cons } & & $0.107^{* * * *}$ \\
\hline & & $(55.65)$ \\
\hline$N$ & 3553 & 3560 \\
\hline
\end{tabular}

